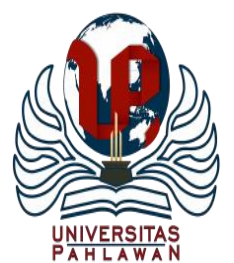

Edukatif : Jurnal Ilmu Pendidikan Volume 3 Nomor 4 Tahun 2021 Halm 1724 - 1733

EDUKATIF: JURNAL ILMU PENDIDIKAN

Research \& Learning in Education

https://edukatif.org/index.php/edukatif/index

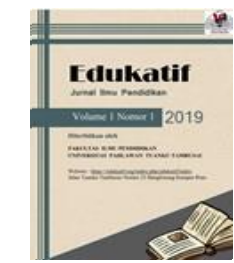

\title{
Analisis Istilah Kampus Ilmiah, Religius, dan Edukatif dalam Tinjauan Teori Realms $O f$ Meaning Karya Phenix
}

\author{
Purwati $^{1 凶}$, Sofyan Sauri ${ }^{2,}$ Aiman Faiz ${ }^{3}$ \\ Universitas Pendidikan Indonesia, Indonesia ${ }^{1}$ \\ Universitas Pendidikan Indonesia, Indonesia ${ }^{2}$ \\ Universitas Muhamadiyah Cirebon, Indonesia ${ }^{3}$ \\ E-mail : $\underline{\text { Purwati_purwati@upi.edu }}{ }^{1}$, sofyansauri@upi.edu $^{2}, \underline{\text { aimanfaiz@umc.ac.id }}^{3}$
}

\begin{abstract}
Abstrak
Terjadi kontradiksi antara teori dan realitas pendidikan di perguruan tinggi yang memunculkan kasus oknum mahasiswa yang jauh dari nilai, terutama nilai utama ilmiah, religius, dan edukatif. Tujuan penelitian ini menganalisis nilai ilmiah, religius dan edukatif dengan teori utama Realms of Meaning, ketiga nilai tersebut dan menemukan konsep pendidikan di perguruan tinggi berdasarkan prinsip pendidikan umum. Adapun penelitian ini menggunakan pendekatan kualitatif berupa library research. Analisis data menggunakan analisis enam makna menurut Realm of Meaning. Hasil kajian ini yaitu: 1) ilmiah, religius dan edukatif adalah core values mewujudkan kepribadian utuh mahasiswa; 2) pendidikan berdasarkan hakikat manusia sebagai makhluk rasional, religius, dan berpendidikan; 3) kesadaran nilai adalah kunci mewujudkan mahasiswa berakal, beragama, dan berkarakter; 4) etika termasuk pendidikan umum yang diwujudkan dalam berbagai mata kuliah umum; 5) seni sebagai media pewaris nilai; 6) pendidikan membina roh dan fisik manusia. Dengan hasil penelitian ini diharapkan menjadi pilot project bagi kampus-kampus yang ingin mengembangkan konsep kampus yang ilmiah, edukatif dan religius.
\end{abstract}

Kata Kunci: nilai-nilai ilmiah, edukatif, religius, realm of meaning, phenix.

Abstract

There is a contradiction between the theory and the reality of education in higher education which raises cases of unscrupulous students who are far from values, especially the main scientific, religious, and educational values. The purpose of this study is to analyze scientific, religious and educational values with the main theory of Realms of Meaning, these three values and find the concept of education in higher education based on general education principles. This research uses a qualitative approach in the form of library research. Data analysis used analysis of six meanings according to Realm of Meaning. The results of this study are: 1) scientific, religious and educative are the core values to realize the complete personality of students; 2) education based on human nature as rational, religious, and educated beings; 3) value awareness is the key to realizing students who are intelligent, religious, and have character; 4) ethics including general education which is manifested in various general courses; 5) art as a medium for inheriting values; 6) education fosters the human spirit and body. With the results of this research, it is expected to be a pilot project for campuses that want to develop a scientific, educational and religious campus concept.

Keywords: scientific, educational, religious values, realm of meaning, phenix.

Copyright (c) 2021 Purwati, Sofyan Sauri, Aiman Faiz

$\triangle$ Corresponding author

Email : Purwati_purwati@upi.edu

DOI $\quad$ : https://doi.org/10.31004/edukatif.v3i4.667

ISSN 2656-8063 (Media Cetak)

ISSN 2656-8071 (Media Online)

Edukatif : Jurnal Ilmu Pendidikan Vol 3 No 4 Tahun 2021 p-ISSN 2656-8063 e-ISSN 2656-8071 
1725 Analisis Istilah Kampus Ilmiah, Religius, dan Edukatif dalam Tinjauan Teori Realms Of Meaning Karya Phenix - Purwati, Sofyan Sauri, Aiman Faiz

DOI: https://doi.org/10.31004/edukatif.v3i4.667

\section{PENDAHULUAN}

Pendidikan adalah upaya mengembangkan berbagai potensi manusia (Neolaka \& Neolaka, 2017). Potensi-potensi ini meliputi kemampuan menjadi manusia beriman, berakhlak mulia, cerdas, kreatif, mandiri, terampil, bertanggung jawab, dan demokratis (Undang-Undang Republik Indonesia Nomor 20 Tahun 2003 Tentang Sistem Pendidikan Nasional, 2003). Pendidikan memiliki tujuan mewujudkan manusia dewasa (Sutrisno, 2014). Manusia dewasa adalah manusia yang mandiri dan telah terbina seluruh potensinya sehingga mampu hidup seimbang. Pendidikan tidak bisa dilaksanakan secara parsial agar seluruh potensinya terbina. Jika potensi terbina sebagian saja, maka manusia akan kesulitan menjalani hidup dan mengalami ketidakbermaknaan. Apabila manusia mencapai ketidakbermaknaan maka ia akan jauh dari nilai-nilai kebajikan dalam kehidupannya (Phenix, 1964).

Salah satu upaya untuk membina potensi manusia adalah perguruan tinggi, perguruan tinggi memiliki tugas yang berat dalam mengembangkan nilai, karakter dan kemampuan tambahan yang harus dimiliki mahasiswa (Faiz \& Soleh, 2021: 70). Lebih jauh lagi (Oey-Gardiner et al., 2017; Faiz \& Purwati, 2021: 651) menyebutkan bahawa perguruan tinggi perlu mempersiapkan kerterampilan dalam memecahkan permasalahan dan kemampuan berpikir kreatif, pemecahan masalah dan fleksibilitas dalam kognitif. Artinya perguruan tinggi adalah tempat membina manusia yang sedang berkembang menuju kedewasaan. Upaya pembinaan ini melalui berbagai aktivitas pendidikan seperti perkuliahan, interaksi sosial, budaya, peraturan, pelatihan, penelitian, tugas, dan kegiatan sejenis.

Berdasarkan teori, pendidikan memiliki makna bahwa pelaksanaannya dilakukan secara menyeluruh menyangkut pengetahuan, emosi, keterampilan, dan spiritual manusia (Musfah, 2012). Namun realitas menunjukkan bahwa pelaksanaan belum sesuai dengan teori. Umumnya, pendidikan di Indonesia mengalami hambatan aspek pelaksanaan. Hambatan ini berupa adanya jarak antara das sein dan das solen (Sauri \& Firmansyah, 2010).

Pola pendidikan di perguruan tinggi Indonesia lebih dari 3000 kampus masih berorientasi pada pengajaran (Gunawan, 2012). Pengajaran hanya mengarah pada pengelolaan intelektual. Jika dikaitkan dengan teori internalisasi nilai, pola ini baru mencapai tahap informasi. Tahap informasi adalah tahap paling dasar sebelum tahap keyakinan, sikap, nilai, karakter, kepribadian, dan jati diri (Hakam \& Nurdin, 2016).

Hasil pendidikan terwujud dalam tindakan bermuatan nilai kebajikan (edukatif). Berdasarkan hasil penelitian, ditemukan contoh kasus pergaulan bebas di kalangan mahasiswa (Setyawan et al., 2019). Kasus ini menunjukkan seseorang yang berstatus mahasiswa memiliki pengetahuan nilai kebajikan. Namun, pengetahuan ini belum mampu membuatnya menjadi manusia edukatif.

Penyimpangan ini menunjukkan bahwa potensi yang ada di dalam diri mahasiswa tadi baru sebagian yang dikembangkan. Melakukan tindakan menyimpang artinya memiliki ketidakmampuan memanfaatkan akal, belum bisa mengintegrasikan nilai ketuhanan dalam berpikir, dan ketidakmampuan membuat keputusan matang. Ketidakmampuan memanfaatkan akal menunjukkan jauh dari nilai ilmiah sehingga akal belum berjalan dengan baik dan sulit menjalankan peran sebagai makhluk rasional. Ketidakmampuan mengintegrasikan nilai ketuhanan dalam berpikir menunjukkan jauh dari nilai religius sehingga berani melakukan pelanggaran dan belum mampu menjadi makhluk religius. Ketidakmampuan membuat keputusan matang menunjukkan jauh dari nilai edukatif sehingga salah bertindak dan belum berhasil menjadi makhluk berpendidikan.

Pada kajian ini, terlihat jelas ada kontradiksi antara teori dan realitas pendidikan dalam mewujudkan manusia dewasa. Oleh sebab itu, artikel ini mengkaji kampus ilmiah, religius, dan edukatif berdasarkan Realms of Meaning. Alasannya karena nilai ilmiah, religius, dan edukatif adalah nilai utama (core values) yang melandasi pendidikan holistik mahasiswa sebagai kelompok akademis. 
Nilai ilmiah, edukatif, dan religius perlu dikaji untuk menemukan konsep dasar menyelenggarakan pendidikan di perguruan tinggi. Hal ini berdasarkan beberapa hasil penelitian terkait ketiga nilai tadi yang masih dikaji secara terpisah. Ada tiga penjelasan mengenai inti sari hasil penelitian tersebut. Pertama, kajian nilai ilmiah yaitu sikap ilmiah mahasiswa yang tinggi berpengaruh terhadap tingginya budaya akademik (Nikmah, 2015). Kedua, hasil kajian nilai religius adalah semakin tinggi tingkat religius mahasiswa maka semakin tinggi pula tingkat kesejahteraan subjektifnya (Utami, 2012). Ketiga, kajian nilai edukatif yaitu interaksi edukatif yang dilakukan dosen memberi pengaruh pada perkembangan karakter mahasiswa (Rohani et al., 2013). Pendidikan perlu dilaksanakan berdasarkan hakikat manusia dan ketiga nilai ini selaras dengan hakikat tersebut. Nilai ilmiah, religius, dan edukatif berkaitan dengan hakikat manusia sebagai makhluk rasional, makhluk religius, dan makhluk berpendidikan.

Dengan demikian, pelaksanaan pendidikan dengan fokus pengembangan nilai ilmiah, religius dan edukatif menjadi sebuah keniscayaan sehingga, peneliti merasa penting mengkaji tiga makna nilai tersebut berdasarkan tinjauan teori Phenix yang menjadi tujuan dalam penelitian ini. Dengan harapan hasil penelitian ini menjadi sumber rujukan bagi kampus-kampus yang berminat mengembangkan nilai-nilai tersebut dalam lingkup pendidikan tinggi sehingga menghasilkan khazanah keilmuan yang belum ada sebelumnya.

\section{METODE PENELITIAN}

Penelitian ini menggunakan pendekatan kualitatif berupa research librarians atau penelitian kepustakaan yang menggunakan studi literatur sebagai analisis topik penelitian (Faiz \& Kurniawaty, 2020: 158). Data yang mendukung hasil penelitian diperoleh dari buku dan artikel yang memiliki standar terindeks sinta yang relevan dengan topik penelitian sehingga dapat dijadikan rujukan yang diolah dengan berdasarkan variabel topik penelitian. Pemilihan artikel yang menjadi rujukan dalam penelitian kepustakaan ini dilakukan dengan cara pengumpulan informasi dan data secara mendalam untuk mendapatkan jawaban dari landasan teori nilai-nilai religius, ilmiah dan edukatif. Adapun teori utama yang digunakan adalah teori enam makna Realms of Meaning yang dikemukakan Phenix yaitu makna simbol, sinoptik, sinoetik, etika, estetika, dan empirik. Setelah sumber literatur terkumpul, peneliti menganalisis bagian-bagian yang menjadi fokus analisis makna tersebut.

\section{HASIL DAN PEMBAHASAN}

Pada bagian ini, peneliti akan mengintegrasikan hasil analisis berdasarkan tinjauan studi literatur dari buku dan artikel penelitian terdahulu. Adapun grand theory yang menjadi rujukan utama adalah buku Phenix tahun 1964 yang berjudul realms of meaning. Ketertarikan peneliti menggunakan rujukan utama buku Phenix berdasarkan hasil kajian pengamatan terkait buku realms of meaning yang menjadi salah satu teori utama dalam menganalisis nilai-nilai pendidikan pada jurusan Pendidikan Umum dan Karakter di UPI Bandung. Adapun enam meaning yang dirumuskan oleh Phenix diantaranya; simbolik, sinoptik, sinoetik, etika, estetika, dan empirik. Ke enam makna tersebut diintegrasikan kedalam nilai ilmiah, religius dan edukatif. Lebih jelasnya hasil analisis berdasarkan teori Phenix dengan nilai-nilai tersebut diantaranya:

\section{Ilmiah, Religius, dan Edukatif dalam Makna Simbolik}

Mengacu pada Depdiknas tahun 2008, kata ilmiah memiliki arti sesuai dengan "hukum ilmu pengetahuan" (Departemen Pendidikan Nasional, 2008). Pada konteks ini, kata hukum dapat dipahami sebagai peraturan yang wajib ditaati akademisi. Akademisi adalah sebutan bagi orang berpendidikan tinggi yang selalu memanfaatkan akalnya dalam menilai, bertindak, menemukan solusi, dan dalam aktivitas hidup lainnya. Pada simbol ilmiah terkandung nilai-nilai yang menjadi ciri khas akademisi dalam berpikir menemukan nilai 
1727 Analisis Istilah Kampus Ilmiah, Religius, dan Edukatif dalam Tinjauan Teori Realms Of Meaning Karya Phenix - Purwati, Sofyan Sauri, Aiman Faiz

DOI: https://doi.org/10.31004/edukatif.v3i4.667

kebenaran berdasarkan nilai kritis, jujur, teliti, rasa ingin tahu, menghargai, berani, tanggung jawab, kreatif, tekun, kerja sama, hati-hati, dan lapang dada.

Kata religius ditafsirkan sebagai sifat taat terhadap "agama” (Departemen Pendidikan Nasional, 2008). Simbol ini mewakili karakter orang beragama karena di dalamnya terkandung nilai-nilai ketuhanan yang tertuang dalam perintah dan larangan-Nya. Sedangkan kata edukatif mengandung arti "bersifat mendidik" (Departemen Pendidikan Nasional, 2008). Pada simbol ini, terdapat kata bersifat. Jika berbicara sifat, artinya berbicara nilai. Kata mendidik mengarah pada perbuatan atau aksi nyata berupa tindakan yang memberi manfaat bagi diri sendiri, alam, dan orang lain. Tindakan tadi memiliki makna tidak bertentangan dengan norma-norma yang berlaku di masyarakat. Simbol edukatif mewakili ciri orang berkarakter baik. Tindakannya mengandung nilai-nilai kebajikan, baik itu nilai yang bersumber dari hasil berpikir (pengelolaan akal) maupun keimanan terhadap Tuhan (pengelolaan hati).

Ilmiah, religius, dan edukatif adalah tiga komponen yang dibutuhkan dalam mewujudkan manusia utuh. Manusia utuh adalah manusia yang bertindak berdasarkan nilai-nilai kebajikan sehingga tindakannya menghadirkan manfaat bagi kehidupan (edukatif). Ada tiga penjelasan mengenai hubungan simbol ilmiah, edukatif, dan religius dalam mewujudkan manusia utuh. Pertama, tindakan edukatif dilandasi oleh akal dan keimanan. Kedua, akal membantu manusia menemukan nilai kebenaran guna memperoleh keyakinan menentukan tindakan edukatif. Nilai kebenaran diperoleh melalui proses berpikir ilmiah. Ketiga, manusia tidak mengandalkan akal saja. Pemanfaatan akal didampingi juga oleh nilai-nilai ketuhanan (religius) supaya manusia tidak keliru dalam memanfaatkan akalnya. Keempat, ketika manusia mampu berpikir ilmiah (ilmiah) yang didampingi nilai-nilai ketuhanan (religius), ia dapat memperoleh keyakinan kuat dalam menentukan tindakan bermanfaat (edukatif).

Simbol adalah alat komunikasi dalam menyampaikan sesuatu yang abstrak (Harisah \& Masiming, 2008). Ilmiah, edukatif, dan religius adalah simbol yang mewakili ide perguruan tinggi dalam menyampaikan konsep, tujuan, pelaksanaan, dan ekspektasi kampus dengan menjadikan ketiga nilai tadi sebagai nilai-nilai utama (core values) kampus. Teori interaksi simbolik berpandangan bahwa tindakan manusia hadir karena adanya makna (West \& Turner, 2008). Simbol ilmiah, edukatif, dan religius memiliki makna menggerakkan warga kampus memiliki karakter manusia berakal, beragama, dan berkarakter.

Bagi orang yang mengamatinya, simbol dapat memberi pengaruh terhadap persepsi, sikap, maupun perilakunya (Harisah \& Masiming, 2008). Menurut teori interaksi simbolik, makna akan hadir pada diri manusia ketika ada komunikasi (West \& Turner, 2008). Berdasarkan penjelasan ini, pihak kampus dapat menggerakkan warganya melalui beragam cara seperti penetapan moto kampus, kurikulum, budaya, program, karya, bahasa, perilaku, desain bangunan, etika dosen, etika mahasiswa, konsep pembelajaran (perencanaan, pelaksanaan, dan evaluasi) dan contoh lainnya. Hal-hal ini tidak hanya diwujudkan dalam bentuk kesepakatan dan aturan tersurat. Kesepakatan dan aturan tersurat ini perlu dihidupkan dengan cara melakukan tindak lanjut (respon) atau aksi nyata warga terhadap bentuk-bentuk pergerakan tadi.

\section{Ilmiah, Religius, dan Edukatif Menurut Makna Sinoptik}

Makna sinoptik berkaitan dengan pandangan yang menyeluruh atau komprehensif (Sumantri \& Sauri, 2006). Berdasarkan makna sinoptik, manusia yang berakal, beragama, dan berkarakter perlu memiliki cara berpikir holistik dalam memahami, menganalisis, menimbang pilihan, menyelesaikan masalah, dan menawarkan solusi. Dalam pandangan filsafat misalnya, potensi manusia menurut filsuf muslim Ibn Miskawaih meliputi daya berpikir (al quwwah an natiqah), daya marah (al quwwah al ghadabiah), dan daya syahwat (syahwatal quwwah al syahwatiyah) (Nizar, 2016). Adanya daya berpikir menunjukkan bahwa manusia adalah makhluk rasional. Aristoteles menyebut manusia sebagai binatang rasional atau rational animal (Mesaroş, 2014). 
Dalam analisisnya, Kusbandrijo (2016) mengungkapkan bahwa manusia adalah makhluk pencari kebenaran. Sebagaimana hakikatnya, Tuhan memberi anugerah berupa akal kepada manusia. Akal adalah alasan manusia disebut makhluk rasional dan keberadaannya membuat derajat manusia lebih tinggi dibandingkan makhluk lain di dunia ini. Akal adalah instrumen manusia dalam ikhtiar menemukan kebenaran (Noor, 2017). Akal bisa menghadirkan manfaat dan bisa juga sebaliknya. Hal ini dipengaruhi oleh respon manusia atas akal yang dimilikinya. Berpikir adalah bentuk kerja akal (Noor, 2017). Tanpa berpikir, akal tidak akan menghadirkan manfaat bagi manusia. Manusia perlu memiliki kemauan memanfaatkan akal sebaikbaiknya.

Salah satunya kemampuan berpikir yang termasuk bagian dari tujuan pendidikan umum (Sauri, 2003). Alasannya, setiap manusia dari berbagai lingkungan membutuhkan kemampuan ini. Tujuan manusia berpikir adalah menemukan kebenaran atas objek yang sedang dipikirkannya. Namun, manusia tidak sembarangan dalam melakukan aktivitas berpikir. Tanpa rambu-rambu, manusia akan mengalami kekeliruan, tersesat, atau terjebak. Jika hal seperti ini terjadi, maka manusia sulit dan ragu atas pilihan, keputusan, dan tindakan yang dilakukannya. Pendidikan adalah kunci memaksimalkan kemampuan berpikir, salah satunya melalui pendidikan filsafat di perguruan tinggi dalam berbagai jurusan. Setiap manusia perlu mengenal filsafat karena dapat memberi petunjuk cara berpikir sistematis dan universal (Teng, 2017).

Berpikir kritis adalah aktivitas pencarian kebenaran dengan memanfaatkan akal. Berpikir kritis adalah tanda seseorang memiliki sifat ilmiah. Mempertanyakan makna istilah tertentu (hal paling dasar) adalah contoh berpikir kritis. Hal ini berdasarkan pemikiran Aristoteles yang memiliki prinsip bahwa langkah pertama mempelajari ilmu adalah mengenal dan memahami dahulu berbagai istilah yang biasa hadir dalam ilmu tadi (Rukiyati et al., 2018). Segala sesuatu harus diawali dari hal paling dasar karena dapat membantu seseorang tidak terjebak dengan tafsiran umum yang sudah menjadi budaya, mengecek dan memperbaiki kekeliruan yang belum disadari, dan dapat dipahami sebagai tindakan yang dapat memperkuat pandangan awal.

Merujuk pada makna sinoptik yang didalamnya terdapat makna agama yang menjelaskan bahwa manusia memiliki god spot (titik Tuhan) di bagian otaknya (Ramachandran \& Blakeslee, 1999). Titik ini membuat manusia memiliki kecenderungan alami untuk mencari siapa Tuhan dan keinginan mendekatkan diri pada-Nya ketika sudah mengenal Tuhan. Titik ini adalah faktor yang melandasi manusia disebut sebagai makhluk religius.

Pembinaan agama (spiritual) memiliki kedudukan utama dalam membangun manusia utuh (Sauri, 2006). Manusia holistik tidak berorientasi pada filsafat saja. Sifat kebenaran filsafat adalah subjektif pararelistik yang berarti kebenaran nilai tergantung pada orang, kelompok atau lingkungan tertentu. Bagi sebagian kelompok, nilai dikatakan benar, tetapi bagi kelompok lain bisa dikatakan salah. Adanya perbedaan pengalaman hidup adalah faktor yang memunculkan kontradiksi nilai kebenaran ini. Hal ini berbeda dengan agama. Nilai kebenerannya bersifat mutlak atau absolut. Kebenaran bukan diawali dari skeptis atau kagum, tetapi diawali dari keyakinan karena sumber agama berasal dari Tuhan.

Pandangan religius dalam prinsip Hamka yaitu akan semakin kuat ketika dilengkapi pandangan filsafat (Haris, 2010). Berdasarkan pernyataan ini, nilai-nilai religius yang terkandung dalam agama memiliki fungsi sebagai pemandu manusia dalam menemukan kebenaran dan hasil kajian filsafat dapat memperkuat kebenaran atas nilai-nilai religius yang sudah tertanam di dalam diri.

Sementara dalam pandanga historis yang terkandung dalam makna sinoptik yang memaknai manusia adalah makhluk sejarah. Alasannya, sejarah selalu menyertai pikiran manusia (Teng, 2017). Di dalam sejarah terkandung berbagai nilai kebajikan yang perlu diwariskan kepada generasi baru. Peran manusia sebagai pewaris nilai (edukatif) menunjukkan bahwa ia termasuk makhluk berpendidikan. Orang berpendidikan memiliki ciri hidup berdasarkan nilai dan memiliki motivasi menyebarkan nilai kepada orang lain. Oleh 
1729 Analisis Istilah Kampus Ilmiah, Religius, dan Edukatif dalam Tinjauan Teori Realms Of Meaning Karya Phenix - Purwati, Sofyan Sauri, Aiman Faiz.

DOI: https://doi.org/10.31004/edukatif.v3i4.667

karena itu, Langeveld menyebut manusia sebagai homo educandum dan homo educable (Sanusi \& Suryadi, 2018).

Berdasarkan kajian di atas, konsep kampus dalam membina manusia berakal, beragama, dan berkarakter yaitu: 1) menggunakan prinsip filsafat dalam menemukan kebenaran (wujud nilai ilmiah); 2) memasuki dunia sejarah dalam menelusuri akar masalah dan jawaban atas kebenaran yang sedang dicari itu (nilai ilmiah); 3) menjadikan agama sebagai payung dalam menilai, menelusuri jejak, dan meyakini kebenaran dari proses pencarian tadi (nilai religius); dan 4) mampu menemukan nilai-nilai yang perlu diwariskan dari peninggalan sejarah manusia (nilai edukatif).

\section{Ilmiah, Religius, dan Edukatif Menurut Makna Sinoetik}

Makna sinoetik mengkaji kesadaran manusia secara mendalam (Royani, 2015). Kesadaran diri yaitu memahami apa dan mengapa memiliki perasaan tertentu, penyebab munculnya perasaan itu, serta tahu pengaruh perasaan tadi terhadap orang lain (Maharani \& Mustika, 2016). Kesadaran diri berkaitan dengan kemampuan seseorang dalam mengenal dirinya dan paham tentang tindakan yang perlu dilakukan (Akbar et al., 2018). Kesadaran diri melibatkan akal dan keyakinan yang terwujud dalam tindakan nyata. Edukatif berada di tahap teratas setelah ilmiah dan religius. Di dalam perilaku edukatif terkandung nilai-nilai ilmiah dan religius. Seseorang tidak akan menampilkan perilaku edukatif jika ia tidak mampu menggunakan akalnya dalam menemukan nilai kebenaran (ilmiah) dan tidak menjadikan nilai-nilai ketuhanan (religius) sebagai pedoman mencari nilai kebenaran tadi.

Berdasarkan kajian ini, maka konsep kampus berdasarkan perspektif makna sinoetik yaitu: 1) pendidikan bersifat menyeluruh dan tidak berorientasi pada kognitif dan keterampilan saja; 2) menghadirkan Mata Kuliah Dasar Umum (MKDU) bermuatan nilai karakter dalam membina kepribadian mahasiswa supaya terwujud kesadaran yang datang dari diri sendiri; 3) pembinaan nilai karakter pada mahasiswa tidak sebatas pengetahuan saja, tetapi sampai keyakinan, tindakan, bahkan sampai tahap karakter; dan 4) pembinaan mahasiswa tidak berupa pendidikan transmisi, tetapi dilengkapi juga dengan pendidikan konstruktivisme untuk mengokohkan nilai yang telah diyakini dengan menggunakan berbagai model pembelajaran nilai karakter.

\section{Ilmiah, Religius, dan Edukatif Menurut Makna Etik}

Dari sudut pandang ethics, nilai atau value adalah sesuatu yang dianggap berharga (Sauri, 2017). Nilai memiliki peran penting bagi keberlangsungan hidup manusia (Sauri et al., 2018). Etika adalah ilmu yang mengkaji berbagai nilai yang dibutuhkan manusia dalam menjalani kehidupannya. Manusia adalah makhluk moral (Sauri, 2003). Manusia membutuhkan etika untuk mengembangkan potensinya supaya bermoral. Ilmu ini sebagai solusi mencegah terjadinya dekadensi moral. Adapun maksud dari dekadensi moral yaitu suatu keadaan yang terjadi karena masyarakat mulai mengabaikan nilai-nilai moral yang menjadi pegangan hidupnya (Nurhadi et al., 2015).

Etika adalah ilmu yang mengkaji tingkah laku manusia (Bertens, 2007). Norma merupakan wujud dari makna etika. Norma berisi nilai-nilai yang telah disepakati bersama dan berfungsi sebagai pengatur kehidupan manusia di lingkungan sosial (Sauri, 2015). Etika mengkaji nilai sehingga dikelompokkan ke dalam pendidikan umum. Alasannya, pendidikan umum termasuk program pembinaan kepribadian (Sauri, 2003). Selain itu, pendidikan umum menjadi salah satu konsep pendidikan yang memberikan jalan untuk menjadikan kepribadian manusia lebih humanis dan holistik (Faiz, 2020: 3). Membina kepribadian artinya melakukan pendidikan budi pekerti. Istilah pendidikan ini sama dengan pendidikan karakter atau budi pekerti (Ruyadi, 2010), dimana dalam pendidikan karakter penanaman kebiasaan (habituation) menjadi sebuah keniscayaan (Faiz, 2019: 2). 
Etika dibuktikan melalui sikap tata krama (Haris, 2010). Tata krama sendiri bersifat teknis atau praktis (Sauri, 2013). Perwujudan nilai-nilai etika ini mencakup berbagai lingkungan mulai dari lingkungan keluarga, kampus, masyarakat, maupun lingkungan lainnya. Di lingkungan akademisi, etika sebagai panduan dalam bertindak, baik itu terkait aktivitas di bidang keilmuannya sendiri maupun kehidupan sosial. Contoh etika bermuatan nilai ilmiah yaitu adanya kode etik peneliti dan penulis karya ilmiah. Contoh etika bermuatan religius di lingkungan kampus yaitu adanya kode etik mahasiswa dan dosen dalam beraktivitas di kampus (edukatif), termasuk di dalamnya adalah kode etik peneliti dan penulis juga (ilmiah).

Hakikat etika adalah baik-buruknya tingkah laku (Haris, 2010), perilaku yang sesuai etika mengandung nilai-nilai kebaikan, tidak menimbulkan kerugian melainkan menghadirkan manfaat dan teladan bagi orang lain. Hal ini menunjukkan bahwa perilaku beretika artinya perilaku edukatif (mendidik, tidak merugikan, dan dapat diteladani).

Dengan demikian, dari perspektif etika, konsep kampus ilmiah, edukatif, dan religius yaitu perlu menghadirkan: 1) kode etik perilaku warga kampus; 2) masa orientasi mahasiswa baru; 3) kegiatan ekstrakurikuler atau program pembinaan karakter mahasiswa mulai dari pembinaan pengetahuan, keyakinan, sampai tindakan mahasiswa; 4) interaksi aktif dan interaktif yang dilakukan dosen terhadap mahasiswa saat proses maupun setelah pembelajaran melalui bahasa tulis, lisan, dan bahasa tubuhnya; dan 5) mata kuliah umum yang dapat mengembangkan karakter mahasiswa seperti Pendidikan Bahasa Indonesia, Pendidikan Pancasila, Pendidikan Kewarganegaraan, Pendidikan Agama, Kode Etik Keprofesian, dan mata kuliah lain yang dinilai perlu dan ada kaitannya.

\section{Ilmiah, Religius, dan Edukatif Menurut Makna Estetika}

Seperti yang kita ketahui bahwa Tuhan memberi potensi akal dan rasa pada diri manusia sehingga ia disebut makhluk budaya (Sarinah, 2019). Budaya memiliki tiga unsur yang meliputi cipta, rasa, dan karsa (Zainal, 2015). Contoh manusia melahirkan budaya adalah lahirnya norma sosial, upacara, sastra, seni, dan sejenisnya. Kebudayaan adalah wujud hasil karya manusia (Teng, 2017). Seni adalah bagian dari karya manusia yang meliputi seni musik, tari, sastra, dan seni rupa. Sumbernya dari pemikiran manusia tentang agama, ilmu, dan filsafat (Sauri et al., 2010). Ketiga jenis seni ini diolah oleh akal dan rasa manusia. Pengolahan kedua aspek ini dipengaruhi oleh segala sesuatu yang ditangkap pancaindra manusia dalam kehidupan sehari-hari. Alam, aktivitas, dan peristiwa adalah sumber manusia dalam menangkap ide untuk menyajikan karya. Produk manusia berupa karya adalah representasi kehidupan nyata dan sebagai alat penyampai nilai-nilai kehidupan.

Salah satu alat mewariskan nilai adalah melalui pendidikan (Sauri \& Nurdin, 2019), didalamnya terdapat seni yang termasuk media pendidikan dalam menyampaikan nilai-nilai kebajikan seperti nilai ilmiah, religius, dan edukatif. Seni berperan dalam mewariskan nilai dan membantu manusia memahami nilai.

Dengan demikan, konsep kampus ilmiah, religius dan edukatif menurut makna ini yaitu: 1) perguruan tinggi berperan dalam mewariskan nilai-nilai kebajikan; 2) menyediakan media dalam menyebarkan nilai; 3) menjadikan seni sebagai media pelestarian nilai; 4) menyediakan kesempatan kepada mahasiswa dalam menunjukkan perilaku edukatif melalui seni musik, seni tari, seni rupa, dan seni sastra yang dilandasi nilai ilmiah dan religius.

\section{Ilmiah, Religius, dan Edukatif Menurut Makna Empirik}

Makna empirik berbicara ilmu fisika, biologi, psikologi, dan ilmu sosial (Phenix, 1964). Apabila fisika dan biologi dikaitkan dengan manusia, maka inti sari kedua kajian ini yaitu membahas unsur materi, sedangkan psikologi dan ilmu sosial membahas unsur roh. Menurut aliran dualisme, realitas terdiri dari unsur roh dan materi (Sutrisno, 2014). Oleh karena itu, dalam membina manusia perlu dilakukan secara menyeluruh. Bentuk pembinaan ini diawali dengan menentukan konsep kurikulum pendidikan yang sesuai dengan hakikat 
1731 Analisis Istilah Kampus Ilmiah, Religius, dan Edukatif dalam Tinjauan Teori Realms Of Meaning Karya Phenix - Purwati, Sofyan Sauri, Aiman Faiz

DOI: https://doi.org/10.31004/edukatif.v3i4.667

manusia. Alasannya karena kurikulum berfungsi sebagai penentu arah, isi, dan proses pendidikan ( $\mathrm{Z}$ et al., 2015). Penanaman nilai ilmiah pada diri manusia termasuk pembinaan unsur materi, sedangkan penanaman nilai religius termasuk pembinaan unsur roh. Penanaman nilai edukatif adalah bentuk pembinaan holistik yang menyatukan dua unsur berbeda yaitu materi dan roh.

Berdasarkan pemaparan di paragraf atas, dapat disimpulkan bahwa konsep membangun kampus ilmiah, edukatif, dan religius menurut makna empirik yaitu: 1) pendidikan di perguruan tinggi perlu dilaksanakan secara komprehensif sesuai hakikat manusia; dan 2) menghadirkan mata kuliah umum bermuatan pengelolaan materi dan roh bagi seluruh mahasiswa dari berbagai jurusan seperti mata kuliah keagamaan, filsafat, logika, pendidikan jasmani dan kesehatan, serta pendidikan karakter.

\section{KESIMPULAN}

Dengan demikian hasil analisis teori Realms of Meaning (makna simbol, sinoptik, sinoetik, etika, estetika, dan empirik). Secara garis besar menghasilkan temuan berupa: 1) ilmiah, religius dan edukatif adalah core values mewujudkan kepribadian utuh mahasiswa; 2) pendidikan berdasarkan hakikat manusia sebagai makhluk rasional, religius, dan berpendidikan; 3) kesadaran nilai adalah kunci mewujudkan mahasiswa berakal, beragama, dan berkarakter; 4) etika termasuk pendidikan umum yang diwujudkan dalam berbagai mata kuliah umum; 5) seni sebagai media pewaris nilai; 6) pendidikan membina roh dan fisik manusia. Adapun pengembangan yang berkaitan dengan nilai ilmiah, edukatif, dan religius memberikan gambaran yang bisa digunakakn untuk pengembangan universitas yang ingin menggunakan istilah nilai ilmiah, edukatif dan religius yang ditinjau dari teori Phenix. Kampus mengacu pada makna simbolik yang merujuk pada penetapan moto kampus, kurikulum, budaya, program, karya, bahasa, perilaku, etika dosen, etika mahasiswa, konsep pembelajaran. Secara sinoptik kampus bisa mengadopsi nilai-nilai yang berfokus dalam membina manusia berakal, beragama, dan berkarakter. Dari makna sinoetik, kampus perlu mengembangkan pendidikan yang bersifat menyeluruh dengan menghadirkan Mata Kuliah Dasar Umum (MKDU) bermuatan nilai. Selanjutnya makna etik berorientasi pada berbagai nilai kode etik perilaku warga kampus. Dari sudut pandang estetik perlu menjadikan seni sebagai media pelestarian nilai yang menyediakan kesempatan kepada mahasiswa dalam menunjukkan perilaku edukatif melalui seni musik, seni tari, seni rupa, dan seni sastra yang dilandasi nilai ilmiah dan religius. Yang terakhir dari sudut pandang empirik berorientsasi agar pendidikan dilaksanakan secara komprehensif sesuai hakikat manusia; dan menghadirkan mata kuliah umum bermuatan keagamaan, filsafat, logika, pendidikan jasmani dan kesehatan, serta pendidikan karakter.

\section{DAFTAR PUSTAKA}

Akbar, M. Y. A., Amalia, R. M., \& Fitriah, I. (2018). Hubungan Relijiusitas dengan Self Awareness Mahasiswa Program Studi Bimbingan Penyuluhan Islam (Konseling) UAI. Jurnal Al-Azhar Indonesia Seri Humaniora, 4 (4), 265-270.

Bertens, K. (2007). Etika. PT Gramedia Pustaka Utama.

Departemen Pendidikan Nasional. (2008). Kamus Bahasa Indonesia. Pusat Bahasa.

Faiz, A. (2019). Program Pembiasaan Berbasis Pendidikan Karakter Di Sekolah Aiman Faiz karena kualitas karakter menentukan. PGSD Universitas Muhammadiyah Cirebon, 5(20). https://doi.org/htps://doi.org/10.32534/jps.v5i2.741

Faiz, A. (2020). Pendidikan nilai dan karakter dalam perspektif pendidikan umum di perguruan tinggi. Sosioreligi, 18(2), 1-7.

Faiz, A., \& Kurniawaty, I. (2020). Konsep Merdeka Belajar Pendidikan Indonesia Dalam Perspektif Filsafat Progresivisme. Konstruktivisme: Jurnal Pendidikan Dan Pembelajaran. 
1732 Analisis Istilah Kampus Ilmiah, Religius, dan Edukatif dalam Tinjauan Teori Realms Of Meaning Karya Phenix - Purwati, Sofyan Sauri, Aiman Faiz

DOI: https://doi.org/10.31004/edukatif.v3i4.667

https://doi.org/https://doi.org/10.35457/konstruk.v12i2.973

Faiz, A., \& Purwati. (2021). Koherensi Program Pertukaran Pelajar Kurikulum Merdeka Belajar Kampus Merdeka dan General Education. EDUKATIF: JURNAL ILMU PENDIDIKAN, 3(3), 649-655. https://doi.org/10.31004/edukatif.v3i3.378

Faiz, A., \& Soleh, B. (2021). Implementasi pendidikan karakter berbasis kearifan lokal. JINoP (Jurnal Inovasi Pembelajaran), 7(1), 68-77. https://doi.org/10.22219/jinop.v7i1.14250

Gunawan, H. (2012). Quo Vadis Perguruan Tinggi di Indonesia? In Otonomi Perguruan Tinggi: Suatu Keniscayaan. Yayasan Pustaka Obor Indonesia.

Hakam, K. A., \& Nurdin, E. S. (2016). Metode Internalisasi Nilai-nilai untuk Memodifikasi Perilaku Berkarakter. CV Maulana Media Grafika.

Haris, A. (2010). Etika Hamka Konstruksi Etik Berbasis Rasional-Relig.ius. LKiS.

Harisah, A., \& Masiming, Z. (2008). Persepsi Manusia terhadap Tanda, Simbol, dan Spasial. SMARTek, 6 (1), $29-4$.

Kusbandrijo, B. (2016). Dasar-dasar Logika. Kencana.

Maharani, L., \& Mustika, M. (2016). Hubungan Self Awareness dengan Kedisiplinan Peserta Didik Kelas VIII di SMP Wiyatama Bandar Lampung (Penelitian Korelasional Bidang BK Pribadi). Konseli: Jurnal Bimbingan Dan Konseling, 3 (1).

Mesaroş, C. (2014). Aristotle and Animal Mind. Procedia - Social and Behavioral Sciences, 163, 185-192. https://doi.org/10.1016/j.sbspro.2014.12.305

Musfah, J. (2012). Pendidikan Holistik: Pendekatan Lintas perspektif. Kencana.

Neolaka, A., \& Neolaka, G. A. A. (2017). Landasan Pendidikan Dasar Pengenalan Diri Sendiri Menuju Perubahan Hidup. Kencana.

Nikmah, D. N. (2015). Implementasi Budaya Akademik dan Sikap Ilmiah Mahasiswa. Manajemen Pendidikan, 24(6), 483-490.

Nizar. (2016). Pemikiran Etika Ibn Miskawaih. Jurnal Aqlam, 1 (1).

Noor, J. (2017). Metodologi Penelitian Skripsi, Tesis, Disertasi, \& Karya Ilmiah (1st ed.). Kencana.

Nurhadi, M., Husaini, A., Sauri, S., \& Suryadi, B. (2015). Pendidikan Kedewasaan Perspektif Pendidikan Islami menurut Abdullah Nashih Ulwan dan Implementasinya di Pondok Modern Darussalam Gontor Ponorogo. Ta'dibuna: Jurnal Pendidikan Islam, 4(1), 21-42. https://doi.org/10.32832/TADIBUNA.V4I1.574

Phenix, P. H. (1964). Realms of Meaning. McGraw Hill Book Company.

Ramachandran, V. S., \& Blakeslee, S. (1999). Phantoms in the Brain: Probing the Mysteries of the Human Mind. The Quarterly Review of Biology, 74 (3), 365-366. https://doi.org/https://doi.org/10.1086/393234

Rohani, Elfayetti, Pinem, M., \& Sitompul, M. (2013). Interaksi Edukatif Dosen dengan Mahasiswa dalam Pembangunan Karakter di Fakultas Ilmu Sosial - UNIMED. JUPIIS: Jurnal Pendidikan Ilmu-Ilmu Sosial, 5(1), 103-115.

Royani, M. (2015). Membangun Kepribadian dengan Nilai-nilai Pendidikan Matematika. Math Didactic: Jurnal Pendidikan Matematika, 1 (1), 23-32.

Rukiyati, Purwastuti, L. A., \& Haryatmoko. (2018). Etika Pendidikan. Penerbit ANDI.

Ruyadi, Y. (2010). Model Pendidikan Karakter Berbasis Kearifan Budaya Lokal (Penelitian terhadap Masyarakat Adat Kampung Benda Kerep Cirebon Provinsi Jawa Barat untuk Pengembangan Pendidikan Karakter di Sekolah). Proceedings of The 4th International Conference on Teacher Education; Join Conference UPI \& UPSI, 576-594.

Sanusi, U., \& Suryadi, R. A. (2018). Ilmu Pendidikan Islam. Deepublish.

Sarinah. (2019). Ilmu Sosial Budaya Dasar (Di Perguruan Tinggi). Deepublish.

Sauri, S. (2003). Pengembangan Strategi Pendidikan Berbahasa Santun di Sekolah. Mimbar Pendidikan. No. 
1733 Analisis Istilah Kampus Ilmiah, Religius, dan Edukatif dalam Tinjauan Teori Realms Of Meaning Karya Phenix - Purwati, Sofyan Sauri, Aiman Faiz

DOI: https://doi.org/10.31004/edukatif.v3i4.667

1/Vol. XXII Tahun 2003.

Sauri, S. (2006). Membangun Komunikasi dalam Keluarga (Kajian Religi, Sosial, dan Edukatif). PT Genesindo.

Sauri, S. (2013). Filsafat dan Teosofat Akhlak. Genesindo.

Sauri, S. (2015). Pendidikan Etika dalam Kehidupan Beragama. CV Arfino Raya.

Sauri, S. (2017). Nilai Kearifan Pesantren. Rizqi Press.

Sauri, S., \& Firmansyah, H. (2010). Meretas Pendidikan Nilai. CV Arfino Raya.

Sauri, S., Firmansyah, H., \& Rizal, A. S. (2010). Filsafat Ilmu Pendidikan Agama. CV Arvindo Raya.

Sauri, S., \& Nurdin, D. (2019). Manajemen Pendidikan Berbasis Nilai. PT Refika Aditama.

Sauri, S., Nursyamsiah, N., \& Nurbayan, Y. (2018). A critique of local wisdom values in Indonesia's pesantren. Pertanika Journal of Social Sciences and Humanities, 26(T), 37-50.

Setyawan, S. A., Gustaf, M. A. M., Pambudi, E. D., Fatkhurrozi, M., \& Anwar, S. (2019). Pergaulan Bebas di Kalangan Mahasiswa dalam Tinjauan Kriminologi dan Hukum. Seminar Nasional Hukum Universitas Negeri Semarang, 163-186.

Sumantri, E., \& Sauri, S. (2006). Konsep Dasar Pendidikan Nilai. PT Pribumi Mekar.

Sutrisno, A. N. (2014). Telaah Filsafat Pendidikan (Edisi Revi). Deepublish.

Teng, H. M. B. A. (2017). Filsafat Kebudayaan dan Sastra (Dalam Perspektif Sejarah). Jurnal Ilmu Budaya, 5 (1), 69-75.

Undang-Undang Republik Indonesia Nomor 20 Tahun 2003 tentang Sistem Pendidikan Nasional, (2003).

Utami, M. S. (2012). Religiusitas, Koping Religius, dan Kesejahteraan Subjektif. Jurnal Psikologi, 39(1), 46 66.

West, R., \& Turner, L. H. (2008). Pengantar Teori Komunikasi Analisis dan Aplikasi (3rd ed.). Salemba Humanika.

Z, F. H., Husaini, A., Sauri, S., \& Suryadi, B. (2015). Keimanan kepada Yang Tuhan Mahaesa sebagai Inti Kurikulum Sekolah (Kasus di Sekolah Dasar Islam Terpadu Al-Fatah Bekasi). Ta'dibuna, 4(2), 127150.

Zainal, M. (2015). Pengantar Ilmu Sosial dan Budaya Dasar. Deepublish. 